\title{
Isolasi bakteri resisten merkuri pada urin pasien dengan tumpatan amalgam di puskesmas paniki bawah
}

\author{
${ }^{1}$ Intan P. R. Sompie \\ ${ }^{2}$ Billy J. Kepel \\ ${ }^{2}$ Fona Budiarso
}

\author{
${ }^{1}$ Kandidat Skripsi Fakultas Kedokteran Universitas Sam Ratulangi Manado \\ ${ }^{2}$ Bagian Kimia Fakultas Kedokteran Universitas Sam Ratulangi Manado \\ Email: intanprsompie@gmail.com
}

\begin{abstract}
Mercury is one of the most toxic heavy metals. Although it can be harmful for human health, the use of mercury in daily life virtually covers all aspects of human life, including its use as the material for dental amalgam fillings. The mercury in amalgam may enter the body, be absorbed by the digestive tract, and then be excreted through the urine. There are bacteria known to be resistant to mercury. This stduy was aimed to obtain and identify the mercury-resistant bacteria in the urine of patients with amalgam fillings. This was a descriptive-explorative study using urine samples of 2 patients who had used amalgam fillings for at least 6 months at Puskesmas (primary health care) Paniki Bawah. The samples underwent morphology, physiology, and biochemistry tests at the Microbiology Laboratory of Pharmacy FMIPA Sam Ratulangi University. The results showd that there were 3 genus of mercury resistant bacteria that survived in $10 \mathrm{ppm}, 20 \mathrm{ppm}$, and $40 \mathrm{ppm}$ concentrations of mercury, as follows: Bacillus, Klebsiella, and Staphylococcus. Conclusion: There are 3 genus of mercury resistant bacteria in the urine of patients with amalgam dental fillings.
\end{abstract}

Keywords: mercury, amalgam, urine, bacteria, resistant

\begin{abstract}
Abstrak: Merkuri merupakan salah satu jenis logam berat berbahaya. Walaupun diketahui memiliki dampak buruk bagi kesehatan manusia, namun pemanfaatan merkuri dalam kehidupan sehari-hari hampir meliputi semua aspek kehidupan manusia, termasuk dalam penggunaannya sebagai bahan tumpatan gigi amalgam. Merkuri dalam amalgam akan masuk ke dalam tubuh, diabsorbsi melalui saluran pencernaan, dan dieskresikan melalui urin. Diketahui bahwa terdapat bakteri yang resisten terhadap merkuri. Penelitian ini bertujuan untuk mengetahui dan mengidentifikasi bakteri resisten merkuri yang terdapat pada urin pasien dengan tumpatan amalgam. Jenis penelitian ialah deskriptif eksploratif dengan mengambil sampel urin pada 2 pasien yang menggunakan tumpatan amalgam minimal 6 bulan di Puskesmas Paniki Bawah. Sampel diuji secara morfologi, fisiologi, dan biokimia di Laboratorium Mikrobiologi Farmasi FMIPA Universitas Sam Ratulangi. Hasil penelitian mendapatkan dari berbagai uji yang dilakukan ditemukan 3 genus bakteri resisten merkuri yang bertahan pada konsentrasi merkuri 10 ppm, 20 ppm, dan 40 ppm, yaitu Bacillus, Klebsiella, dan Staphylococcus. Simpulan: Terdapat 3 genus bakteri resisten merkuri pada urin pasien dengan tumpatan amalgam di Puskesmas Paniki Bawah.
\end{abstract}

Kata kunci: merkuri, amalgam, urin, bakteri, resisten

Merkuri merupakan salah satu jenis logam berat berbahaya yang banyak terdapat di alam. ${ }^{1}$ Merkuri diketahui memiliki dampak buruk terhadap kesehatan manusia. ${ }^{2}$
Keracunan merkuri dapat menyebabkan kerusakan sistem saraf pusat, kerusakan ginjal, kerusakan paru-paru, pada janin dapat menimbulkan cacat mental, buta, dan 
serebral palsy, serta bisa meningkatkan angka kematian. ${ }^{3}$ Senyawa merkuri juga dikenal karena aktivitas imunosupresif. ${ }^{4}$

Walaupun diketahui memiliki dampak buruk namun pemanfaatan merkuri dalam kehidupan sehari-hari hampir meliputi semua aspek kehidupan manusia, baik dalam bidang perindustrian, pertanian, dan kedokteran. ${ }^{5}$ Salah satu bentuk pemanfaatan merkuri dalam bidang kedokteran gigi yaitu digunakan sebagai bahan tumpatan gigi, atau yang dikenal dengan tumpatan amalgam.

Amalgam merupakan material yang paling sering digunakan sebagai tumpatan gigi sejak awal abad ke 19 dan sampai sekarang pemakaiannya masih kontroversial karena kandungan merkuri yang terdapat pada amalgam. Selama bertahun-tahun tumpatan amalgam menjadi pilihan karena harganya yang relatif murah, pemasangan yang mudah, kuat, tahan lama, dan memiliki efek bakteriostatik. ${ }^{4}$ Suatu penelitian di Rumah Sakit Gigi dan Mulut Manado menunjukkan bahwa amalgam merupakan material tumpatan yang paling sering digunakan dibandingkan material lain, yaitu sebesar $52,91 \%{ }^{6}$

Logam merkuri yang terkandung dalam amalgam bersifat tidak larut dalam air, namun bakteri dalam rongga mulut mampu mengubah logam merkuri menjadi ion $\mathrm{Hg}^{2+}$ yang larut dalam air. ${ }^{7,8}$ Ion $\mathrm{Hg}^{2+}$ yang terekspos ke cairan mulut kemudian akan masuk ke dalam tubuh manusia melalui sistem pencernaan, pernafasan dan penyerapan melalui mukosa mulut. $\mathrm{Hg}$ yang diserap melalui jaringan paru-paru dan pencernaan kemudian akan masuk ke aliran darah dan berikatan dengan protein yang memiliki gugus $\mathrm{S}-\mathrm{S}$ yang berfungsi untuk mentransfer merkuri ke hati dan ginjal. Merkuri kemudian diekskresikan melalui kulit (keringat), ginjal (urin), dan saluran cerna (feses). ${ }^{2,7,8}$

Akibat seringnya terpapar dengan merkuri yang berasal dari tumpatan amalgam, maka diasumsikan bahwa bakteri normal yang terdapat pada saluran kemih memiliki sifat resisten terhadap merkuri. Hal ini menunjukkan bahwa merkuri dari tumpatan amalgam dapat memicu bakteri resisten. Bakteri dikatakan resisten terhadap merkuri jika bakteri tersebut tetap dapat hidup walaupun sering terpapar dengan merkuri.

Bakteri resisten merkuri memiliki peran dalam proses detoksifikasi merkuri dengan cara mereduksi ion $\mathrm{Hg}^{2+}$ menjadi ion $\mathrm{Hg}^{0}$ oleh enzim merkuri reduktase, dari yang sebelumnya bersifat toksik menjadi kurang toksik. Detoksifikasi merkuri oleh bakteri resisten merkuri dapat terjadi karena bakteri tersebut memiliki gen resistensi merkuri yaitu operon mer, yang strukturnya berbeda-beda untuk setiap jenis bakteri. $^{9}$

Penelitian ini bertujuan untuk mengetahui dan mengidentifikasi jenis bakteri resisten merkuri yang terdapat pada urin pasien dengan tumpatan amalgam di Puskesmas Paniki Bawah.

\section{METODE PENELITIAN}

Jenis penelitian yang digunakan yaitu deskriptif eksploratif. Penelitian dilakukan sejak bulan Oktober hingga November 2016, yang bertempat di Puskesmas Paniki Bawah dan Laboratorium Mikrobiologi Farmasi FMIPA Universitas Sam Ratulangi. Populasi dalam penelitian yaitu bakteri dalam urin pasien dengan tumpatan amalgam di Puskesmas Paniki Bawah, Kota Manado. Sampel yang diambil pada penelitian ini yaitu 2 sampel urin dari pasien di Puskesmas Paniki Bawah yang menggunakan tumpatan amalgam minimal 6 bulan. Variabel penelitian yaitu bakteri resisten merkuri.

Prosedur kerjanya dimulai dengan pengambilan sampel, yaitu urin porsi tengah. Sampel kemudian dibawa ke Laboratorium Mikrobiologi Farmasi FMIPA Unsrat. Penelitian dimulai dengan isolasi bakteri resisten merkuri dengan konsentrasi $\mathrm{HgCl}_{2}$ masing-masing $10 \mathrm{ppm}$, $20 \mathrm{ppm}$, dan $40 \mathrm{ppm}$ pada media nutrient agar dan diinkubasi selama 18-24 jam. Setelah itu dilakukan identifikasi bakteri dengan uji morfologi, fisiologi, dan biokimia. Uji morfologi dilakukan dengan pewarnaan Gram. Bakteri yang berwarna 
ungu merupakan bakteri Gram positif sedangkan bakteri yang berwarna merah merupakan bakteri Gram negatif.

Uji fisiologi dilakukan dengan uji motilitas. Uji bersifat positif apabila terlihat adanya pertumbuhan melebar dari bekas tusukan jarum Öse.

Uji biokimia meliputi uji fermentasi karbohidrat, uji indol, uji katalase, uji lisin dekarboksilase, uji $\mathrm{H}_{2} \mathrm{~S}$, dan uji sitrat. Pada uji fermentasi karbohidrat diamati adanya perubahan warna media dan terbentuknya gas yang kemudian dibandingkan dengan tabung kontrol. Pembentukan asam terlihat sebagai perubahan warna substrat karbohidrat dari warna merah menjadi warna kuning dan pembentukan gas terlihat dengan adanya gelembung udara dalam tabung durham. Pada uji indol, hasil positif bila kultur berwarna merah pada saat penambahan reagen. Pada uji katalase apabila terjadi pembentukan gelembung udara di dalam tabung reaksi, maka hasilnya positif. Tahap selanjutnya menggunakan uji lisin dekarboksilase. Reaksi positif ditunjukkan dengan perubahan warna pada media menjadi warna lembayang (violet), sedangkan reaksi negatif ditandai dengan warna kuning pada media. Selanjutnya pada uji $\mathrm{H}_{2} \mathrm{~S}$, bila terbentuk warna hitam pada media berarti bakteri mampu membentuk $\mathrm{H}_{2} \mathrm{~S}$ maka hasilnya positif tapi bila terbentuk warna kuning berarti bakteri tidak mampu membentuk $\mathrm{H}_{2} \mathrm{~S}$ maka hasilnya negatif. Pada uji sitrat, hasil yang positif ditunjukkan dengan adanya perubahan warna media dari hijau menjadi biru dan hasil yang negatif apabila tidak terjadi perubahan warna pada media.

Hasil yang diperoleh kemudian ditabulasi dan dibandingan dengan data pada buku Bergey's Manual Determinative of Bacteriology.

\section{HASIL PENELITIAN}

Setelah diinkubasi selama 18-24 jam, dilakukan pengamatan terhadap koloni bakteri yang terbentuk pada media nutrient agar yang mengandung merkuri masingmasing 10 ppm, 20 ppm, dan 40 ppm. Dari pengamatan pada setiap cawan petri didapatkan sejumlah koloni bakteri yang tumbuh pada masing-masing media nutrient agar. Koloni yang terbentuk semuanya berwarna putih keruh.

Dari semua koloni yang terbentuk dilakukan seleksi berdasarkan warna dan bentuk. Berdasarkan hasil seleksi, didapati total 10 koloni. Koloni-koloni tersebut kemudian diinokulasi ke dalam media agar miring masing-masing tabung 1 isolat, dengan jumlah 10 isolat. Setiap isolat diberikan kode atau nama sesuai dengan konsentrasi merkuri dan nomor sampel, yaitu A.10.1, A.10.2, B.10.1, B.10.2, A.20.1, A.20.2, A.20.3, B.20.1, A.40.1, dan B.40.1. Setelah inkubasi selama 18-24 jam, isolat yang terbentuk pada agar miring berwarna putih keruh, yang selanjutnya isolat tersebut akan digunakan untuk identifikasi melalui uji morfologi, uji fisiologi, dan uji biokimia.

Uji morfologi dilakukan dengan pewarnaan Gram. Hasil yang didapatkan dari pewarnaan Gram yaitu isolat A.10.1, B.10.1, B.10.2, A.20.1, dan B.40.1 merupakan basil Gram positif. Isolat A.10.2, A.20.2, dan A.40.1 didapatkan basil Gram negatif. Isolat A.20.3 dan B.20.1 didapatkan kokus Gram positif.

Uji fisiologi dilakukan dengan uji motilitas, yaitu untuk mengetahui kemampuan bakteri dalam melakukan pergerakan. Pada pengujian ini didapatkan hasil uji motilitas negatif pada semua isolat. Artinya tidak terdapat pertumbuhan menyebar dari bekas tusukan pada media agar.

Uji fermentasi karbohidrat dilakukan menggunakan media Triple Sugar Iron Agar (TSIA) bersama-sama dengan uji $\mathrm{H}_{2} \mathrm{~S}$. Dari pengamatan didapatkan hasil bahwa pada semua isolat terjadi perubahan warna media yang sebelumnya berwarna merah menjadi berwarna kuning baik pada bagian dasar (butt) maupun pada bagian miring (slant). Ditemukan juga pembentukan gas pada bagian dasar (butt), maka dapat disimpulkan bahwa bakteri yang terdapat pada semua isolat dapat memfermentasikan semua jenis karbo- 
hidrat, baik glukosa, laktosa, dan sukrosa, disertai pembentukan gas $\mathrm{CO}_{2}$ sebagai sisa proses fermentasi.

Pada uji indol didapatkan hasil semua isolat negatif, yaitu tidak terjadi pembentukan cincin merah pada permukaan media setelah ditetesi dengan reagen Kovacs. Hal ini menunjukkan bahwa bakteri-bakteri yang terdapat pada semua isolat tidak memiliki enzim triptofanase yang dapat mendegradasi asam amino triptofan.

Hasil uji katalase yang dilakukan dengan menggunakan media nutrient broth menunjukkan hasil positif pada semua isolat, yaitu dengan terbentuknya gelembung gas. Hal ini berarti bakteribakteri tersebut memiliki enzim katalase yang mengubah $\mathrm{H}_{2} \mathrm{O}_{2}$ menjadi $\mathrm{H}_{2} \mathrm{O}$ dan $\mathrm{O}_{2}$.

Pada uji lisin dekarboksilase ini didapatkan hasil positif hanya pada isolat A.20.1, yaitu terjadinya perubahan warna media menjadi warna lembayung (keunguan) sedangkan 9 isolat lainnya didapatkan hasil negatif, dimana tidak terjadi perubahan warna pada media.

Uji $\mathrm{H}_{2} \mathrm{~S}$ yang menggunakan media TSIA didapatkan hasil negatif pada semua isolat, artinya tidak terbentuk endapan berwarna hitam pada dasar media (butt).

Hasil pengujian terhadap 10 isolat didapatkan positif pada semua isolat. Hal ini ditunjukkan dengan adanya perubahan warna media Simmons' Citrate Agar yang sebelumnya berwarna hijau kemudian berubah menjadi warna biru.

Setelah dilakukan identifikasi bakteri melalui serangkaian uji, yang meliputi uji morfologi, uji fisiologi, dan uji biokimia, hasilnya kemudian digabungkan dalam bentuk tabel untuk digunakan dalam penentuan jenis bakteri.

Isolat A.10.1, B.10.1, B.10.2, A.20.1, dan B.40.1 memiliki gambaran basil Gram positif pada pewarnaan Gram. Uji motilitas, uji indol, dan uji $\mathrm{H}_{\mathrm{s}} \mathrm{S}$ kelimanya menunjukkan hasil negatif, sedangkan uji katalase, uji sitrat, dan uji fermentasi karbohidrat menunjukkan hasil positif. Pada uji lisin dekarboksilase didapatkan hasil positif pada isolat A.20.1, sedangkan keempat isolat lainnya, yaitu A.10.1,
B.10.1, B.10.2, dan B.40.1 didapatkan hasil negatif. Berdasarkan hasil uji tersebut, maka kelima isolat ini dapat digolongkan dalam bakteri genus Bacillus. ${ }^{10}$

Isolat A.10.2, A.20.2, dan A.40.1 memiliki gambaran basil Gram negatif pada pewarnaan Gram. Ketiga isolat tersebut menunjukkan hasil negatif pada uji motilitas, uji indol, uji $\mathrm{H}_{2} \mathrm{~S}$, dan uji lisin dekarboksilase, hasil positif pada uji fermentasi karbohidrat, uji sitrat, dan uji katalase. Berdasarkan hasil uji di atas, maka ketiga isolat ini dapat digolongkan dalam bakteri genus Klebsiella. ${ }^{10}$

Isolat A.20.3 dan B.20.1 memiliki gambaran kokus Gram positif pada pewarnaan Gram. Kedua isolat ini juga menunjukkan hasil uji motilitas dan uji biokimia yang sama, yaitu hasil negatif pada uji motilitas, uji indol, uji $\mathrm{H}_{2} \mathrm{~S}$ dan uji lisin dekarboksilase, sedangkan pada uji fermentasi karbohidrat, uji sitrat, dan uji katalase hasilnya sama-sama positif. Berdasarkan hasil tersebut, maka isolat A.20.3 dan B.20.1 ini digolongkan ke dalam bakteri genus Staphylococcus. ${ }^{10}$

\section{BAHASAN}

Salah satu usaha untuk detoksifikasi merkuri yaitu dengan menggunakan bakteri resisten merkuri yang memiliki kemampuan dalam mereduksi merkuri. Kemampuan ini dimungkinkan karena bakteri tersebut memiliki gen resistensi merkuri, operon mer. ${ }^{9,11}$

Penelitian dengan mengambil sampel urin dari pasien dengan tumpatan amalgam di Puskesmas Paniki Bawah yang kemudian dilakukan isolasi bakteri dengan penambahan $\mathrm{HgCl}_{2}$ menunjukkan adanya pertumbuhan bakteri resisten merkuri. Hal ini dibuktikan dengan adanya pertumbuhan koloni pada media nutrient agar.

Berdasarkan hasil penelitian menggunakan uji morfologi, uji fisiologi, dan uji biokimia terhadap 10 isolat didapatkan 3 genus bakteri yang teridentifikasi. Ketiga genus tersebut adalah Bacillus, Klebsiella, dan Staphylococcus.

Genus Bacillus merupakan bakteri batang Gram positif, aerob besar yang 
berbentuk rantai. Sebagian besar anggota genus ini adalah organisme saprofit yang lazim terdapat dalam tanah, air, dan udara serta pada tumbuh-tumbuhan, seperti Bacillus cereus dan Bacillus subtilis. Ciri khas bakteri genus Bacillus adalah selselnya tipikal, berukuran 1 x $3-4 \mu \mathrm{m}$, mempunyai ujung persegi dan tersusun dalam rantai panjang. Memiliki spora yang terletak di tengah basilus nonmotil. Uji katalase positif pada sebagian besar spesies. ${ }^{10,12}$

Bacillus merupakan bakteri yang bersifat kosmopolit dan memiliki resistensi terhadap banyak logam berat seperti kromium, arsen, selenium, dan juga terhadap merkuri. Spesies bakteri dalam genus Bacillus memiliki resistensi yang berbeda-beda terhadap merkuri. ${ }^{13}$ Berdasarkan beberapa penelitian, beberapa spesies Bacillus mampu mengakumulasi logam merkuri sehingga dapat mengurangi konsentrasi merkuri di media tumbuhnya seperti Bacillus sp. 68\%, Bacillus megaterium 98\%, Bacillus sphaericus $47 \%$, dan Bacillus cereus $94 \% .^{13,14}$

Genus Klebsiella memiliki bentuk bakteri batang Gram negatif, ukuran $0,5 \mu \mathrm{m}$ x 3,0 $\mu \mathrm{m}$, tidak berspora, memiliki kapsul yang besar dan teratur, dan merupakan bakteri yang nonmotil. Bakteri genus ini mampu memfermentasikan karbohidrat, tidak mampu menghasilkan indol, serta memberikan hasil yang positif pada uji sitrat dan uji lisin dekarboksilase. ${ }^{10,12,13}$ Salah satu spesies Klebsiella yaitu Klebsiella pneumoniae mampu menurunkan kadar merkuri secara kontinyu sampai dengan $100 \%$ dalam waktu 10 hari, tanpa kehilangan aktifitasnya. ${ }^{9}$

Genus Staphylococcus adalah bakteri dengan sel berbentuk sferis Gram positif, berdiameter sekitar $1 \mu \mathrm{m}$, dan biasanya tersusun dalam kelompok seperti anggur yang tidak teratur. Staphylococcus memiliki kemampuan memfermentasikan karbohidrat secara lambat. Beberapa tipe Staphylococcus merupakan flora normal kulit dan membran mukosa manusia, namun dapat juga bersifat patogen. Bakteri genus ini tidak motil dan tidak membentuk spora. Yang membedakannya dengan bakteri genus streptococcus adalah kemampuannya untuk memproduksi katalase. . $^{12,14}$

Hasil yang didapatkan pada penelitian ini berbeda dengan hasil yang didapatkan oleh Gagola $\mathrm{R}$ pada penelitian yang dilakukan di Puskesmas Bahu Manado, dimana dari 14 isolat yang diuji ditemukan 6 genus bakteri resisten merkuri yang bertahan sampai konsentrasi $40 \mathrm{ppm}$, yaitu Alcaligenes, Neisseria, Planococcus, Marinococcus, Streptococcus, dan Morococcus. $^{2}$

Bakteri dikatakan resisten merkuri apabila bakteri mampu bertahan pada konsentrasi $\mathrm{HgCl}_{2} 10 \mathrm{ppm}$ atau lebih. ${ }^{7}$ Kemampuan reduksi merkuri setiap bakteri berbeda-beda. Perbedaan resistensi ini berhubungan dengan mekanisme respon bakteri terhadap merkuri yang secara umum bervariasi, yaitu: (1) penghambatan metabolisme seluler sehingga pertumbuhan sel terhambat atau mati; (2) induksi kerja operon resistensi merkuri sehingga bakteri tetap hidup; atau (3) terbentuknya plasmid dengan gen resistensi merkuri. ${ }^{11}$

Uji resistensi bakteri menunjukkan bahwa bakteri genus Bacillus dan Klebsiella mampu bertahan hingga konsentrasi $\mathrm{HgCl}_{2} 40$ ppm sedangkan bakteri genus Staphylococcus hanya mampu bertahan hingga konsentrasi $\mathrm{HgCl}_{2}$ 20 ppm.

Resistensi bakteri terhadap logam merkuri dapat melalui mekanisme biosorpsi dan bioakumulasi. Mekanisme biosorpsi merupakan proses pasif, sehingga logam tidak meracuni bakteri sedangkan mekanisme bioakumulasi merupakan proses aktif dimana logam berat dapat meracuni sel bakteri. Mekanisme biosorpsi berhubungan dengan adanya eksopolisakarida (EPS) pada dinding sel bakteri yang berfungsi sebagai pengkelat logam berat di permukaan sel. Molekul kompleks pada dinding sel bakteri terdiri dari peptidoglikan yang tersusun oleh molekulmolekul yang lebih sederhana antara lain fosforil, karboksil, dan asam amino yang mempunyai muatan negatif. Muatan negatif 
akan berinteraksi dengan ion atau molekul bermuatan positif di lingkungan luarnya sehingga berbentuk ikatan ligan. Ion logam bermuatan positif, sehingga secara elektrostatik akan terikat pada permukaan sel. Interaksi antara ion logam dan dinding sel bakteri Gram positif terutama Bacillus $s p$., menunjukkan adanya peranan gugus karboksil pada peptidoglikan dan gugus fosforil pada polimer sekunder asam teikoat dan teikuronat. ${ }^{13}$

\section{SIMPULAN}

Dari hasil isolasi bakteri resisten merkuri pada urin pasien dengan tumpatan amalgam di Puskesmas Paniki Bawah diperoleh 10 isolat bakteri yang memiliki kemampuan mereduksi merkuri dan terdapat 3 genus bakteri yang teridentifikasi, yaitu genus Bacillus, Klebsiella, dan Staphylococcus.

\section{SARAN}

Sebaiknya dilakukan penelitian lebih lanjut dengan menggunakan metode lain, yaitu biologi molekuler serta menambah uji biokimia lainnya untuk mengetahui lebih jauh peran bakteri-bakteri resisten merkuri.

Pada saat melakukan seleksi koloni, sebaiknya dihitung dulu total jumlah koloni yang tumbuh pada setiap konsentrasi sehingga diketahui perbedaan banyaknya koloni yang tumbuh pada masing-masing konsentrasi.

\section{DAFTAR PUSTAKA}

1. Badan Pengawas Obat dan Makanan. Merkuri dan dampaknya terhadap kesehatan manusia. [diakses pada tanggal 19 Agustus 2016]. Tersedia pada

http://ik.pom.go.id/v2015/artikel/ME RKURI-UTK-KORAN-TERBIT.pdf

2. Gagola R, Fatimawali, Manampiring AE. Bakteri resisten merkuri pada urine pasien tumpatan amalgam poli gigi puskesmas Bahu. eBM 2013;1:103340.

3. Pamuryanto R. Dampak kesehatan akibat merkuri. Disampaikan pada lokakarya penutupan kampanye nasional: Penyadaran bahaya merkuri dan penggunaan teknologi pengolahan emas yang lebih aman; 21 Februari 2007; Kasongan.

4. Pundogar SRD, Bautista JR, Teves FG. Prevalence of mercury-resistant and antibiotic-resistant bacteria found in dental amalgam. Int Res J Biological Sci. 2014;3:1-4.

5. Alfian Z. Merkuri: antara manfaat dan efek penggunaannya bagi kesehatan manusia dan lingkungan. Disampaikan pada pengukuhan jabatan guru besar tetap Universitas Sumatera Utara; 1 Mei 2006; Medan.

6. Wigati PR, Pangemanan DHC, Parengkuan WG. Gambaran penggunaan bahan tumpatan di rumah sakit gigi dan mulut PSPDG fakultas kedokteran Unsrat tahun 2015. Pharmacon. 2016;5:44-9.

7. Mogi KT, Kepel B, Bodhi W. Bakteri resisten merkuri $(\mathrm{Hg})$ pada plak gigi pasien dengan tumpatan amalgam di puskesmas Bahu [Skripsi]. Manado: Universitas Sam Ratulangi; 2013.

8. Sukartini E. Penglepasan kadar $\mathrm{Hg}$ dalam urin setelah restorasi amalgam yang di triturasi secara manual. [cited 19 Agustus 2016]. Available from: http://pustaka.unpad.ac.id/wpcontent/uploads/2010/08/penglepasan _kadar_hg_dlm_urin_setelah_restoras i_amalgam.pdf.

9. Kepel B, Fatimawali. Penentuan jenis dengan analisis gen 16SrRNA dan uji daya reduksi bakteri resisten merkuri yang diisolasi dari feses pasien dengan tambalan amalgam merkuri di puskesmas Bahu Manado. Jurnal Kedokteran Yarsi. 2015;23:45-55.

10.Holt JG, Krieg NR, Sneath PHA, Staley JT, Williams ST. Bergey's manual of determinative bacteriology (9th ed). USA: Williams and Wilkins, 1994.

11.Fatimawali. Daya reduksi merkuri isolat bakteri yang diisolasi dari urine pasien di puskesmas Bahu Manado. Pharmacon. 2013;2:109-15.

12.Brooks GF, Butel JS, Morse SA. Mikrobiologi kedokteran Jawetz, Melnick, \& Adelberg (23 ed). Jakarta: EGC, 2007.

13.Sholikah U, Kuswytasari ND. Uji potensi genera Bacillus sebagai 
bioakumulator merkuri. [cited 1 Desember 2016]. Available from: http://digilib.its.ac.id/public/ITSpaper-23658-1508100045-Paper.pdf

14.Zarkasyi H. Biosorpsi logam merkuri (Hg) oleh Bacillus megaterium asal hilir sungai Cisadane [Skripsi]. Jakarta: Universitas Islam Negeri Syarif Hidayatullah; 2008.

15.Karsinah, Lucky HM, Suharto, Mardiastuti HW. Batang negatif
Gram. In: Staf pengajar fakultas Kedokteran UI, penyunting. Buku Ajar Mikrobiologi Kedokteran (Edisi revisi). Jakarta: Binarupa Aksara, 1994.

16. Warsa UC. Kokus positif gram. In: Staf pengajar fakultas Kedokteran UI, penyunting. Buku Ajar Mikrobiologi Kedokteran (Edisi revisi).Jakarta: Binarupa Aksara, 1994. 